\title{
New Challenges for Urban History: Culture, Networks, Globalization
}

\author{
Marjatta Hietala \\ University of Tampere, Finland \\ e-mail: marjatta.hietala@uta.fi
}

Received: 19 April 2012; Accepted: 5 October 2012; Published online: 8 January 2013

\begin{abstract}
Urban history is a very lively and dynamic research field, showing strict parallelism with the fast increasing of the urban population. Today, competitiveness is one of the key aims for cities in the globalized world. Factors such as accessibility and infrastructure, industry, human capital, innovation, and investment, green spaces, affordable housing, business support and quality of education are necessaries. However, the OECD recognizes three dilemmas in this strategic vision, concerning the spill over of metro-regions, the public strategic vision, and the relationship between economic dynamism and the liveable city. Today urban historians are facing some general challenges: comparative aspects are needed; also interdisciplinarity to develop cooperation between disciplines; and for maintaining the professional status of academic urban history. The expanding networks between towns and cities, and the meeting places as conferences and exhibitions are considered, as they are the multitudinous challenges and threats, especially for those cities suffering continuously of major natural and man-made disasters. Moreover, new amalgams of hazard are being created in metropolitan areas with overlapping natural, technological, biological and social risks, exposing more people and places, needing safety and security.
\end{abstract}

KEYWORDS: city; urban history; comparative history; mega-cities; risks; environment

Citation/Cómo citar este artículo: Hietala, M. (2012) "New Challenges for Urban History: Culture, Networks, Globalization”. Culture \& History Digital Journal 1(2): e008. doi: http://dx.doi.org/10.3989/chdj.2012.008

RESUMEN: Nuevos retos en Historia Urbana: Cultura, Redes, Globalización.- La historia urbana es un campo de investigación muy vivo y dinámico, mostrando un paralelismo estricto con el rápido incremento de la población urbana. La competencia es hoy uno de los objetivos claves para las ciudades en el mundo globalizado. Factores tales como la accesibilidad y las infraestructuras, la industria, el capital humano, la innovación y la inversión, los espacios verdes, la vivienda accesible, el apoyo a los negocios y la calidad de la educación son necesarios. Sin embargo, la OCDE reconoce tres dilemas en esa visión estratégica, el desarrollo de las metrópolis, la visión estratégica pública y la relación entre el dinamismo económico y la habitabilidad de la ciudad. Hoy se enfrentan los historiadores urbanos a algunos retos generales: la necesidad de aspectos comparativos, también la interdisciplinariedad para desarrollar la cooperación entre disciplinas y para mantener el status profesional de la historia urbana académica. Las redes expansivas entre pueblos y ciudades, y los lugares de encuentro como conferencias y exposiciones son considerados, así como los múltiples retos y amenazas, especialmente para aquellas ciudades que sufren continuamente los mayores desastres por la naturaleza o el hombre. Más aun, nuevas combinaciones de azares están siendo creados en las áreas metropolitanas con riesgos superpuestos naturales, tecnológicos, biológicos y sociales, exponiendo más gentes y lugares, que necesitan seguridad y protección.

PALABRAS CLAVE: ciudad; historia urbana; historia comparada; megápolis; riesgos; medio ambiente

Copyright: (C) 2012 CSIC. This is an open-access article distributed under the terms of the Creative Commons AttributionNon Commercial (by-nc) Spain 3.0 License. 


\section{INTRODUCTION}

European urban history is a very lively and dynamic field at present. The several hundred participants at the biennial conferences of the European Association of Urban Historians demonstrate this. Of major concern in the current research and debate is the role of cities in the process of globalization, networking and economic, social and cultural innovations.

Today, competitiveness is one of the key aims for cities in the globalized world. Factors such as accessibility and infrastructure, industry, human capital and the workforce can be mentioned as major determinants of a city's competitiveness. In addition, entrepreneurship, innovation, and investment are factors which are important for facilitating new business growth and product development, while playing an even more important role in fostering the growth of a new economy that centres on knowledge, creation and innovation. Cities compete to attract and retain mobile factors such as labour and capital. Indeed, cities also compete by providing the greatest quantity or optimum combination of local factors such as green spaces, affordable housing, business support and quality of education for families (OECD, 2006). Chief amongst these are economic opportunities, which are sought through a sustainable growth vision of 'competitiveness' and 'liveability'. However, the OECD also recognizes three dilemmas in this strategic vision. The first concerns the spill over of metroregions, those sprawling conglomerations of urban people. The report questions whether metro-regions have become major centres of growth in contemporary economies, and cites greater accessibility, lower transaction costs, social capital and urban agglomeration as positive externalities for businesses, but equally so public authorities, educational institutes and local civic associations keen to benefit from increased competition and liveability. For all their benefits, though, there remain various negative externalities associated with large conglomerations of population. These include congestion costs, dilapidated or obsolescent infrastructure, and also weak social, political and fiscal cohesion, which together dilute the impact of spatial planning on a city's growth prospects. The second dilemma concerns the public strategic vision. The authors describe the risks of developing policies based on a focused strategic vision, citing the example of the Montreal metropolitan region as evidence of the diversity of specialized targeted clusters in a multiplicity of different metro-regions. The third dilemma concerns the relationship between economic dynamism and the liveable city. The authors emphasize that there exists considerable evidence that an attractive and functional metropolitan environment is not contrary to economic growth, noting several examples of how public authorities regulate air pollution, energy utilization and conservation, renewable energy sources and water conservation.

Various infrastructural indicators are identified when ranking the most liveable cities. Mercer, (2011), for example, is based on 39 indicators, which include the political and social environment, schools, recreational facilities, health and sanitation. According to this, the top three ranking cities worldwide are Vienna, Zurich and Auckland, and, if personal safety is exemplified, Helsinki is third on the list. Mercer's rankings can be contrasted with others, such as Sakia Sassen's, which are based on explicit economic factors. In these, when the location of headquarters of private companies is quantified, many metropolitan cities rank higher than non-metropolitan ones (Sassen, 2002: 71-115). But much of this is not new, since history tells us that a city's urban infrastructure has always been built with reference to that of other towns, even if this has been done through different processes and channels than at present.

These developments pose a challenge for urban historians. A key concern is why certain cities at particular times, for instance North Italian cities in the Renaissance, Antwerp in the 16th century, London in the 18th century, Berlin in the early 20th century and Helsinki in the late 20th century, are particularly innovative. What factors promote an innovative or creative milieu -education, ethnicity or internationalization? We can also ask what might be the link between crisis and innovation and how far do major upheavals in existing conditions provide a stimulus for new ideas and developments. What kinds of factors that we find today give challenges for urban historians in the globalized world?

Some general challenges:

1. Comparative aspects are needed. There is a lack of serious comparative historical research not only between European cities but worldwide. I would like to ask how long can we concentrate only on our own cities.

2. Interdisciplinarity to develop cooperation between various disciplines worldwide.

3. Maintaining the professional status of academic urban history.

\section{THE GROWTH OF URBAN HISTORY AS AN ACADEMIC FIELD. A BEGINNING FOR COMPARISONS AND NETWORKING}

I would like to start this presentation by analysing some of the roots of urban history in Europe and by explaining first the institutional and other factors that have had impact on the growth of urban history as an academic field and on growing interest in urban phenomena. Secondly, I will pay attention to the fields where worldwide comparisons are possible and where cooperation between various disciplines is needed, such as culture, networks and innovations. 
When analysing main trends in urban history or the development of urban history as a field, the first challenge comes from the growth of urban population: $48.6 \%$ of the world's population lives in cities and in the EU countries this figure is $76 \%$ of the population. For solving the problems of these megalopolises we historians could offer research for town officials based on historical sources. For example, how decision makers have managed to solve various problems concerning infrastructure (e.g. water, sewage and housing). The world's most populous urban agglomerations are outside Europe. First, Tokyo comes with $33,800,000$ inhabitants, then Seoul with $23,800,000$ people and Mexico City with 22,800,000 followed by Bombay, Delhi, New York, Jakarta, Sao Paulo, Manila, Los Angeles, Shanghai, Osaka, Cairo, Calcutta, Karachi, Guangzhou and Buenos Aires. Of European cities, only Moscow is ranked among the 20 largest urban agglomerations (18th with $13,500,000$ inhabitants), then comes Beijing and Dhaka in Bangladesh and number 21 is Istanbul with $12,400,000$ inhabitants. $^{1}$

Since the beginning of the 20th century there has been only a limited range of work in urban history in most countries, whether on the pre-industrial or modern periods. The main studies in urban history were made in writing of the historical developments of individual towns, as in local history biographies. This type of urban history was very popular in the United Kingdom and the Nordic countries. Sweden was a forerunner in coordinating local and urban history. The Institute for local history (Stadshistoriska institutionen) was founded in Stockholm at the beginning of 1920s.

Since the 1960s, when urban history emerged as a distinctive sub-discipline, it has attracted endless questions about the autonomy of its realm, both among its followers and its critics, not least over whether the city was a dependent or an independent variable. $^{2}$ There were questions about the academic focus. Was it possible to create a new field with its apparatus of chairs, research funds and dedicated organizations? One of the distinctions that emerged from this discussion was between those who claimed that cities were cohesive and active social bodies, and those who insisted that they were a node in systems of cities that were fuelled by exogenous economic and social processes.

At the end of the 1970s the Maison des Sciences de l'Homme in Paris, through the initiative of Maurice Aymard, was the leader in organizing a series of international roundtables on urban history in Paris, London, Lille and elsewhere. These brought together leading scholars such as Anthony Sutcliffe, Penelope Corfield, Bernard Lepetit, Herman Diederiks and Lynn Lees. These meetings started the first debate about the comparative study of European urban history. The serious analysis of European cities was also encouraged in the 1980s by other developments: major publications by Jan de Vries, Lynn Hollen Lees and Paul Hohenberg and Paul Bairoch, all of which in different ways sought to provide a framework for understanding the European City (Vries, 1984; Hohenberg and Lees, 1995; Bairoch, 1988).

The establishments of various new research centres such as the Centre of Urban History at Leicester University, Institut für vergleichende Städtegeschichte in Münster helped to professionalize the field of urban history. Networks between European urban historians were strengthened by urban journals. Urban History (earlier Urban History Yearbook) published in Leicester, Journal of Urban History and Informationen für Stadtgeschichte published in Berlin as well as Planning Perspectives.

One of the oldest organizations in the history of towns and cities is the Commission Internationale pour l'histoire des villes (Commission for the history of towns), founded in 1955. One of its main tasks has been to launch projects with comparative perspectives, such as the construction and deconstruction of towns. ${ }^{3}$ As an affiliated member of the Comité International de Sciences Historiques (CISH), the Commission is required to participate in the international congresses organized by CISH, which take place every fifth year. At the end of the five-year-period, a report which synthesizes the work is presented in a public setting at the International Congress.

Recently a strong impulse has been given to the publication of historical atlases with the creation of the Atlas Working Group in order to coordinate the work of the various countries. An example of the comparative projects of the Commission is the decision to produce town atlases edited in the individual countries, but with homogenous criteria. The background for this project can be found in the post-war situation. During the 1950s, most European cities lay in ruins and the idea of the German professors Edith Ennen (Cologne) and Heiz Stoob (Münster) was to produce historic town atlases to help town citizens to understand the economic and demographic development of their own towns over the centuries. The idea was to show the topography, shape and development of certain towns and cities over time. At the moment almost 400 atlases have been published on European towns. After the collapse of the Soviet Union, urban historians in the New Eastern Republics (Czech Republic, Hungary, Poland, Croatia) have started their own atlas projects as well. ${ }^{4}$ Eighteen historic town atlases have been published in the Scandinavian countries. The most recent one in Scandinavia is the Historic Towns Atlas of HelsinkiHelsingfors (Hietala et al. 2009).

In 1989 the Leicester Centre for Urban History in cooperation with Maurice Aymard and Bernerd Lepetit from Paris, Herman Diedricks from Leiden and Herman van der Wee from Leuven secured the funding from the European Commission to establish the European Association of Urban Historians. 
The increasingly successful conferences of the Association, the first held in Amsterdam in 1992, have reflected the growing dynamism of the subject in most European countries, with a proliferation of workshops and seminars. In these bi-annual conferences there are sessions covering all time periods from the medieval and the early modern period to the most modern periods. Presentations at these conferences include an extraordinary variety of economic, social, political, cultural, gender and visual issues of interest to a range of disciplines, from allotment gardens to public houses and civic tensions, from tramways to retail shops, from water supply and sewage to urban cadastres, from port cities to innovative metropolises and from cats to elites in cities.

One of the key elements distinguishes urban history from old-style town history (urban biographies) is its comparative ambition. When someone is interested in comparisons concerning demographic or economic trends in modern time, statistical yearbooks and historical statistics published in all countries are valuable sources of material (Mitchell, 1988 and 1998). Real problems arise when we want to make comparisons between phenomena that cannot be measured quantitatively, such as emotions, or when the source material is fragmentary or different legislation among countries to another makes comparisons difficult. We can encounter problems even when analysing modern history. For example, if we want to compare the educational level of citizens in different countries and cities, problems might arise because school systems and administrative practices vary from country to country and from town to town. The only way for making comparisons is to use as an indicator of educational level school years (years spent at the primary, secondary, upper secondary, vocational, university levels) or as a broader "metric", information on literacy (literate-non literate people). ${ }^{5}$

The 19th century saw a boom in the collection of material for comparisons of infrastructure from railways to gas and electricity, and from water supply to sewage. From the end of the 19th century onwards we can find comparative statistics such as the German statistical yearbook of cities (Deutsches Statistisches Jahrbuch der Städte), the Municipal Year Book in England and a large number of comparative statistical tables in municipal and professional journals. ${ }^{6}$ There are excellent sources for modern urban history produced by the United Nation and its organizations (WHO, FAO, UNESCO) and by the OECD as well the World Bank. Recently there have been attempts to gather all valuable material for comparisons in the long run by Angus Maddison (OECD) in The World Economy. A millennial perspective is packed with over 150 tables, boxes and figures pulling together an incredible array of hard-to-find facts both large and small. The book offers a rare insight into the history and political influence of national accounts and national accounting (Maddison, 2001).
According to Peter Clark methodologically one of the fundamental problems remains the failure of urban historian to develop a robust comparative framework or template which would enable researchers to analyse developments between cities, regions and countries (Clark, 1995). He also gives good examples of successful comparative research. Projects on certain types of cities such as capitals are easy to compare, and the same concerns port cities. Clark's own interest has been in small towns and environment. This project investigated key comparative aspects of the making and contestation of open space and its environmental significance in four leading European cities. It is the first project of its type in the field of urban studies. The project was interdisciplinary and international, bringing together the natural and social sciences and humanities, and involving the participation of leading overseas institutions in Russia, Sweden and England (Clark, 2006).

\section{NETWORKS}

At the end of the 19th and the beginning of the 20th century it became evident that cities and towns had started to form their own ever-expanding network. Mutual co-operation across national borders was being established, first on a regional and then on a national basis, soon blooming into an international phenomenon. Contributing to this process was the emergence of increasingly specialized groups of experts and professionals who were under pressure to keep up with the latest developments in their fields of expertise and with the improvement of communications. Moreover, European and American cities competed in demonstrating how progressive they were and how far they had adopted modern technology. In the decision-making process, municipal officials observed each other's activities and adopted what they regarded useful, thus facilitating the inter-city transfer of innovations, whether changes in municipal institutions or technological applications. Developments were further facilitated by exhibitions and professional congresses that officials and experts, such as engineers and architects, attended, the professional journals they read and by the systematic records and statistics that they kept. Factfinding tours made by individual experts were of great importance. The destinations and determinations of those tours can be analysed from a sociological perspective also by examining the reference groups that the experts, institutions and cities defined for themselves. In other words, with which development they wanted to identify. Researchers today pay attention not only to the transfer process itself but also to cultural values as a part of this process.

Cooperation and networks between municipal officials and policy-makers and the transfer of municipal knowledge in global perspective have been studied in the book Another Global City. Historical Explorations into the Transnational Municipal 
Moment, 1850-2000. In this book, Saunier (2008) distinguished two waves of municipalization: the first one the late nineteenth and early twentieth century and a second wave which followed World War II, when former colonial possessions gained autonomy and adopted the nation-state framework for their former metropolises.

During the first period of municipalisation, municipal authorities in European cities -at least in Scandinavia- developed a follow-up system of knowhow, which consisted of reading studies and printed articles and international statistical comparisons, using the experience of decision-makers in other cities obtained from documents of city councils and municipal boards, statements of experts and opinions of professional associations, personal experience and observation, travel reports, and foreign experts who were invited for discussion (Hietala, 2003). Interest in the organizational or technical know-how that municipal governments used to create and maintain fledgling policies of housing, planning, fire-fighting or public health seems quite parochial. Know-how, from the last decades of the 19th century, was circulated across borders by municipal officials, technicians, firms, scholars and reformers.

The interchange of urban policy recipes and methods was a basic ingredient of the municipal scene in the 19th century. Local authority networking was on the map from the early 20th century onwards and more generally some cities had held leading places in the organization of the world economy for centuries. We can argue that the current international activities of municipal urban governments, especially in terms of creating links with one another across borders, had some historical precedents not only in the celebrated Hanseatic League, but also in circuits that took shape during the 19th century (Sellers, 2003). Globalization is far from new and cities have not suddenly globalized but rather de- and re-globalized.

The role of local political practices in constructing and conquering global city status is now a case in point, and Saskia Sassen stresses that this is an underdeveloped subject. There is a lack of interest in what municipal governments did between the 19th century and recent times. According to P. J. Taylor, with the emergence of a state-centred political and economic world order from the Westphalia treaties to the late 20th century, cities as political units became irrelevant for world city scholars: "Cities became nationalized, mere components of nation-states, cogs in national economies" (Taylor, 2004: 15).

\section{MEETING PLACES: CONFERENCES AND EXHIBITIONS}

Inter-city co-operation manifested itself at town congresses and meetings, where municipal officials discussed common economic, social and cultural questions while city exhibitions provided a forum for demonstrating the progress made in various sectors of municipal life and in the implementing of public utilities. The process of establishing professional associations, which first occurred in Britain and the USA parallel to the development of industrialism, urbanization and improving educational services, increased the professional identity of experts. Furthermore, the associations also strengthened the groups' credibility in relation to other groups and society. Such associations and organizations often developed further into real pressure groups.

It has been estimated that from 1886 to the end of the 19th century there were 853 international congresses, and 2,271 such conferences between 1900 and 1914 held in various fields. In his studies of urban planning, Anthony Sutcliffe has called this increasing internationalism of cities and towns "creative internationalism" (Sutcliffe, 1981). Alexander Geppert's (2009) research illustrates that International Exhibitions from 1851 to 1951 include 100 different exhibitions held in more than twenty countries from Jamaica to Japan. At the end of the 20th century progress was a definitive goal, and the aim of the municipal congresses and civic exhibitions was to show others how advanced and skilled the management of civic affairs could be. This in turn strengthened feelings of civic pride creating motivational environment for the spreading of innovations.

\section{CONCLUSION: THREATS AND CHALLENGES ${ }^{7}$}

Many of the problems that have been tackled through institutionalized and personalized networks throughout nineteenth and twentieth century Europe are today topical across the developing world. Historically, the need to keep up with the latest developments has been of vital importance for small countries and cities such as Helsinki, Oslo and Stockholm, located far away from Western European metropolises. The pattern remains, yet it has shifted its geographical focus towards the global South. The main problems and challenges faced now, and in the future, are the growth of mega-cities, their offshoots of slums, and their manifold environmental problems: carbon dioxide, dust and noise pollution, as well as climate change and their resultant catastrophes, which have thus far included floods and hurricanes. The issue of effectively preparing for natural disasters, including adopting regional warning devices, is at the top of the agenda for supranational institutions such the United Nations at the moment.

Even today, amongst the challenges faced by cities and towns, are the common problems concerning the (re-)building of infrastructure and growing demand for a multitude of different services. Service demand has become particularly acute in the mega-cities of the developing, as much as the developed world: Mexico City and Delhi, as well as Tokyo and New York, are 
common examples of mega-cities. These exploding cities are weaving extraordinary new urban networks, corridors and hierarchies, which as yet show no end to their growth. The problems of such global metropolises include intense traffic congestion, a severe lack of clean water in the urban periphery, incapacitated sewerage systems, and social and ethnic residential segregation. Within these mega-cities are mega-slums inhabited by millions of impoverished city dwellers. In 2005, the eight largest ones were in Mexico City, Caracas, Bogota, Lima, Lagos, Baghdad, and Gauteng (Soweto) (Davis, 2006: 1-49).

The challenges are multitudinous. While we talk about creating sustainable cities, we also now discuss 'resilient cities', that is those that persevere regardless of major natural and man-made disasters. Moreover, at a time when digital communication networks play an increasingly vital role in fostering urban growth, global terrorism threatens the very vulnerability of this urban infrastructure. The 21st century's cities are susceptible not only to overt attacks on buildings, but also to the covert disruption of cyber attacks on the nodes and links of critical networks (Vale and Campanella, 2005).

In their book, Crucibles of Hazard: Megacities and Disasters in Transition, the authors from the International Geographical Union's Study Group conclude that the natural disaster potential for the world's megacities is expanding at a pace far in excess of the rate of urbanization (Mitchell, 1999: 15-47). Moreover, new amalgams of hazard are being created in metropolitan areas with overlapping natural, technological, biological and social risks, exposing more people and places to environmental hazards. Safety and security have, in the long-term, become the common interest for cities. The vulnerability of mega-cities is obvious. This is a major challenge also for urban historians.

\section{ACKNOWLEDGEMENTS}

This article is based on a paper held at the meeting of Japanese historians and Comité international des sciences historiques/International Committee of Historical Sciences, in Tokyo, 11/12 September, 2009.

\section{NOTES}

1. http://world.mongabay.com/nnish/population/.html [accessed 08/October/2012].

2. This debate can be seen in the pages of the dedicated journals Urban History and Journal of Urban History, as well as from a series of articles and chapters, including Lampard (1963), Rodger (1993), and Jansen (1996).

3. http://www.historiaurbium.org/english/attivita en.html [accessed 08/October/2012]

4. http://www.wien.gv.at/kultur/archiv/kooperationen/lbi/staedteat las/bibliographie/index.html [accessed 08/October/2012].

5. In some countries such as Sweden and Finland we have demographic data (on births and deaths) from 1749 onwards.

6. I myself have used comparative statistics when I compared infrastructural services in German and English cities at the turn of the 20th century (Hietala 1987)

7. This chapter is based on Hietala (2008).

\section{REFERENCES}

Bairoch, Paul (1988) Cities and Economic Development: From the Dawn of History to the Present. University of Chicago Press.

Clark, Peter (editor) (1995) Small towns in Early Modern Europe. Cambridge University Press, Cambridge, ed. de la Maison des Sciences de l'Homme, Paris.

Clark, Peter (editor) (2006) The European City and Green Space. London, Stockholm, Helsinki and St. Petersburg, 1850-2000. Ashgate, Padstow.

Davis, Mike (2006) Planet of Slums. Verso, London, New York.

Geppert, Alexander C.T. (2009) Fleeting Cities. Imperial exhibitions in Fin-de-Siècle Europe. Palgrave Macmillan, Basingstoke.

Hietala, Marjatta (1987) Services and Urbanization at the Turn of the Century. The Diffusion of Innovations. Studia Historica 23, Finnish Historical Society, Helsinki.

Hietala, Marjatta (2003) "Transfer of German and Scandinavian Administrative Knowledge: Examples from Helsinki and the Association of Finnish Cities, 1870-1939', In: Jahrbuch für europäische Verwaltungsgeschichte (JEV). Nomos Verlagsgesellschaft, Baden-Baden, pp. 109-130.

Hietala, Marjatta (2008). In Another Global City: Historical Explorations into the Transnational Municipal Moment, 1850-2000, Saunier, Pierre-Yves and Ewen, Shane. Palgrave Macmillan, New York, pp. 184-193

Hietala, Marjatta; Helminen, Martti and Lahtinen, Merja (editors) (2009) Helsinki - Helsingfors. Historiallinen Kaupunkikartasto - Historic Towns Atlas. Helsingin kaupungin tietokeskus/Kaupunginarkisto (Helsinki Urban Facts), Helsinki.

Hohenberg, Paul M. and Lees, Lynn Hollen (1995) The Making of Urban Europe, 1000-1994. Harvard University Press.

Jansen, Harry S.J. (1996) "Wrestling with the angel: on problems of definition in urban historiography', Urban History, 23: 277-299. doi: http://dx.doi.org/10.1017/S0963926800016874

Lampard, Eric (1963) "Urbanization and social change: on broadening the scope and relevance of urban history', In: The historian and the city, Handlin, Oscar and Burchard, John, MIT Press, Cambridge Mass., pp. 225-247.

Maddison, Angus (2001) The World Economy. A millennial perspective. OECD Development Centre Studies, OECD Publishing, Paris.

Mercer (2011) Quality of Living Worldwide City Rankings. http:// www.mercer.com/press-releases/quality-of-living-report-2011 [accessed 08/October/2012]

Mitchell, Brian R. (1988) Abstract of British Historical Statistics. Cambridge University Press, Cambridge.

Mitchell, Brian R. (1998) International historical statistics: Europe 1750-1993. 4th ed. Macmillan Reference, London; Stockton Press, New York.

Mitchell, James K. (editor) (1999) Crucibles of Hazard. Megacities and Disasters in Transition. United Nations University Press, Tokyo.

OECD (2006) "Competitiveness, Liveability and Strategic Vision". In: OECD Territorial Reviews: Competitive Cities in the Global Economy, 55: 85-153. http://browse.oecdbookshop. $\mathrm{org} / \mathrm{oecd} / \mathrm{pdfs} /$ product/0406041e.pdf [accessed 08/October/ 2012]

Rodger, Richard (1993) Theory, practice and urban history. In: European Urban History, Rodger, Richard. Leicester University Press, Leicester, pp. 1-18.

Sassen, Saskia (editor) (2002) Global Networks, Linked Cities. Routledge, New York.

Saunier, Pierre-Yves (2008) "Introduction. Global City, Take 2: A view from Urban History", In: Another Global City: Historical Explorations into the Transnational Municipal Moment, 1850-2000, Saunier, Pierre-Yves and Ewen, Shane. Palgrave Macmillan, New York, pp. 1-18.

Sellers, Jeffrey M. (2003) "Transnational urban associations and the State: contemporary Europe compared with the Hanseatic League', In: Formation und Transfer städtischen Verwaltungswissens, Randeraad, Nico. Jahrbuch für Europäische Verwaltungsgeschichte Band 15, Nomos Verlagsgesellschaft, Baden-Baden, pp. 289-308. 
Sutcliffe, Anthony (1981) Towards the Planned City: Germany, Britain, the United States and France 1780-1914. Comparative Studies in Social and Economic History No. 3, Blackwell, Oxford.

Taylor, Peter J. (2004) World City Network. A Global Urban Analysis. Routledge, London.
Vale, Lawrence J. and Campanella, Thomas J. (editors) (2005) The Resilient City: How Modern Cities Recover from Disaster. Oxford University Press, New York.

Vries, Jan de (1984) European Urbanization 1500-1800. Methuen and Co., London. 